\title{
Optical fractionation of chlorophyll and primary production for coastal waters of the Southern Ocean
}

\author{
Mark A. Moline · Barbara B. Prézelin
}

\begin{abstract}
Our objective was to quantify the potential variability in remotely sensed chlorophyll $a(\mathrm{Chl} a)$ and primary productivity in coastal waters of the Southern Ocean. From data collected throughout the springs/ summers of 1991-1994, we calculated the proportion of water column Chl $a$ and primary productivity within the upper optical attenuation length $\left(K_{\text {par }}^{-1}\right)$ and the satellite-weighted depth. The temporal variability was resolved every 2-3 days and was observed to be greater within years than between years. Three-year averages $(n=223)$ revealed that $10.2 \pm 3.6 \%$ of total $\mathrm{Chl} a$ and $14.8 \pm 6.5 \%$ of production occurred within satelliteweighted depth in predominantly Case I waters. The average values were twice as high within $K_{\mathrm{par}}^{-1}$, $24.1 \pm 8 \%$ of total Chl $a$ and $34 \pm 9 \%$ of production respectively. Masked in these long-term averages are very large changes occurring on short time scales of seasonal blooms. We observed that the patterns of Chl $a$ vertical distribution within blooms are also subject to taxonomic influence and dependent upon the physiological state of the phytoplankton. Highest proportions of water column Chl $a$ in the first optical depth were measured during the rapid onset of surface cryptophyte blooms each year, i.e. $50 \%$ within $K_{\text {par }}^{-1}$ and $30 \%$ above the satellite-weighted depth. Lowest fractions, $6 \%$ and $2 \%$ of biomass within $K_{\text {par }}^{-1}$ and satellite-weighted depth respectively, were associated with peak bloom conditions independent of taxonomy. Our analyses suggest that satellite-dependent models of
\end{abstract}

M.A. Moline ( $\square)$

Biological Sciences Department,

California Polytechnic State University,

San Luis Obispo, CA 93407, USA

e-mail: mmoline@calpoly.edu

B.B. Prézelin

Department of Ecology, Evolution and Marine Biology and the Marine Science Institute, University of California, Santa Barbara, CA 93106, USA
Chl $a$ and subsequent chlorophyll-dependent primary production will be challenging to develop for the nearshore Southern Ocean, especially given the potentially high natural variability in the vertical distribution of Chl $a$ driven by physical forcing, the photoadaptive abilities of polar phytoplankton, and taxonomic influences.

\section{Introduction}

Estimates of water column phytoplankton biomass and biomass-dependent primary production are important biological parameters derived from interpretations of water-leaving radiance $L_{\mathrm{u}}(\lambda)$, measured by ocean color satellite sensors (Smith 1981; Morel and Berthon 1989; Sathyendranath and Platt 1989; cf. Mobley 1994). Such calculations required some knowledge of the depth distribution of phytoplankton biomass relative to the maximum depth of satellite detection of chlorophyll $a$ (Chl $a$ ) absorption signals. The concentration and vertical distribution of Chl $a$ are generally unknown below the depth of the first attenuation length $\left(K_{\text {par }}^{-1}\right)$ and the satellite-weighted depth. To estimate the total water column biomass, algorithms based upon remotely sensed satellite data have had to incorporate some assumption(s) regarding the vertical distribution of Chl $a$ (Platt and Sathyendranath 1988; Morel and Berthon 1989; Lewis 1991; Morel 1991; Sathyendranath et al. 1991; Arrigo et al. 1994, 1998). One approach is to employ idealized Chl $a$ profiles with or without consideration of location, season and/or changing mixing regimes. Another approach is to assume a direct log-log relationship between surface $\mathrm{Chl} a$ and the average Chl $a$ or the fraction of water-column $\mathrm{Chl} a$ distributed above some absolute depth or optical depth (Holm-Hansen and Mitchell 1991; Smith et al. 1996, 1998). The inaccuracies in such approaches are often unknown due to insufficient in situ data comparing $\mathrm{Chl} a$ distribution with optical depths on different time or space scales. 
Berhrenfeld and Falkowski (1997) demonstrated that the majority of variance in primary production estimates results from uncertainty in the depth-integrated phytoplankton Chl $a$.

Satellite estimates of water column phytoplankton biomass and biomass-dependent primary production are also made more difficult when waters contain significant terrigenous inputs. Such waters are classified as Case 2 waters (Gordon and Morel 1983) and are thought to include many of the nearshore regions of coastlines overlying continental shelves. Much of the difficulty in estimating Chl $a$ biomass in Case 2 waters is due to the dominant influence on $L_{\mathrm{u}}(\lambda)$ by high concentrations of dissolved organics, as well as detrital and inorganic particles, found in terrigenous inputs. The result is a masking the smaller contribution by phytoplankton absorption.

Until recently, the accumulation of satellite imagery of Chl $a$ biomass distribution for the Southern Ocean has progressed more slowly than in temperate and tropical latitudes due to infrequent satellite passes and the general cloudiness of the region. With SeaWifs now providing more frequent and spectrally resolved satellite images, efforts are increasing to use satellite observations to predict $\mathrm{Chl} a$ biomass and primary productivity for the Southern Ocean. Logistic constraints for fieldwork in the Southern Ocean have limited the amount of ocean data needed to validate assumptions within the satellite estimates. The presence of several water masses, sudden and severe storms, as well as rapidly changing light fields during a 6-month growing season, result in high in situ variability in hydrographic, optical and biological parameters that determine remotely sensed signals of phytoplankton biomass in the Southern Ocean. This variability may well be higher than those generally measured for coastal regions at lower latitude. For instance, our recent analyses of variability of water column photosynthetic cross section for Antarctic nearshore coastal waters showed that the average value was similar to those determined for temperate and tropical seas. However, the range of values for water column photosynthetic cross section in the Southern Ocean varied 50 -fold over the year and up to 15 -fold on time scales of a few days (Claustré et al. 1997).

The objective of the present study is to quantify the potential variability in remotely sensed Chl $a$ and primary productivity in coastal waters of the Southern Ocean. Using data sets collected during each of the springs and summers of 1991-1994, we determined the temporal variability in the fraction of total water column $\mathrm{Chl}$ and primary productivity within the upper optical attenuation length $\left(K_{\text {par }}^{-1}\right)$ and the satellite-weighted depth for nearshore coastal waters of the Antarctic Peninsula. The data set is appropriate, not only for its length of coverage, but also for its high frequency of sampling (every $2-3$ days), thereby providing the resolution needed to make assessments on several seasonal and sub-seasonal time scales.

\section{Materials and methods}

Sampling

Over the austral spring/summer period from November 1991 to January 1994, a total of 1140 discrete water samples were collected at the Long Term Ecological Research (LTER) stations B and E (Sta B/E; Fig. 1) for concurrent determinations of optical and biological parameters related to phytoplankton ecosystem dynamics. Sta B is a shallow nearshore station $(\sim 75 \mathrm{~m})$, while Sta $E$ is a significantly deeper $(\sim 280 \mathrm{~m})$ and more exposed station located on the northern edge of the Bismarck Strait. The distance between Sta B and Sta E is ca. $3 \mathrm{~km}$. Water column sampling was conducted every 2-3 days from a Mark V Zodiac and, whenever possible, samples were collected within a few hours of solar noon. Moline and Prézelin $(1996,1997)$ give a more detailed description of the sampling strategy.

\section{Phytoplankton pigmentation}

Aliquots of all whole water samples were analyzed for the algal pigments using the reverse-phase HPLC procedures of Wright et al. (1991). One-liter samples were filtered on $0.4-\mu \mathrm{m}$ nylon Nuclepore filters and extracted in $3 \mathrm{ml} 90 \%$ acetone for $24 \mathrm{~h}$ in the dark at $-20^{\circ} \mathrm{C}$. Pigment separation was achieved with the aid of a Hitachi L-6200A pump and an L-4250 UV/VIS variable wavelength detector $(436 \mathrm{~nm})$ equipped with a Waters Resolve $\mathrm{C}_{18}$ column $(3.9 \times 300 \mathrm{~mm} ; 5 \mu \mathrm{m})$. Peak identities of algal extracts were determined by comparing their retention times with pure pigment standards. Pigment data were used to estimate phytoplankton standing crop (Chl $a$; see Table 1 for symbols and abbreviations) and as chemotaxonomic markers to differentiate between algal groups; for example, alloxanthin is a specific marker for cryptophytes (Gieskes and Kraay 1983). From the class-specific

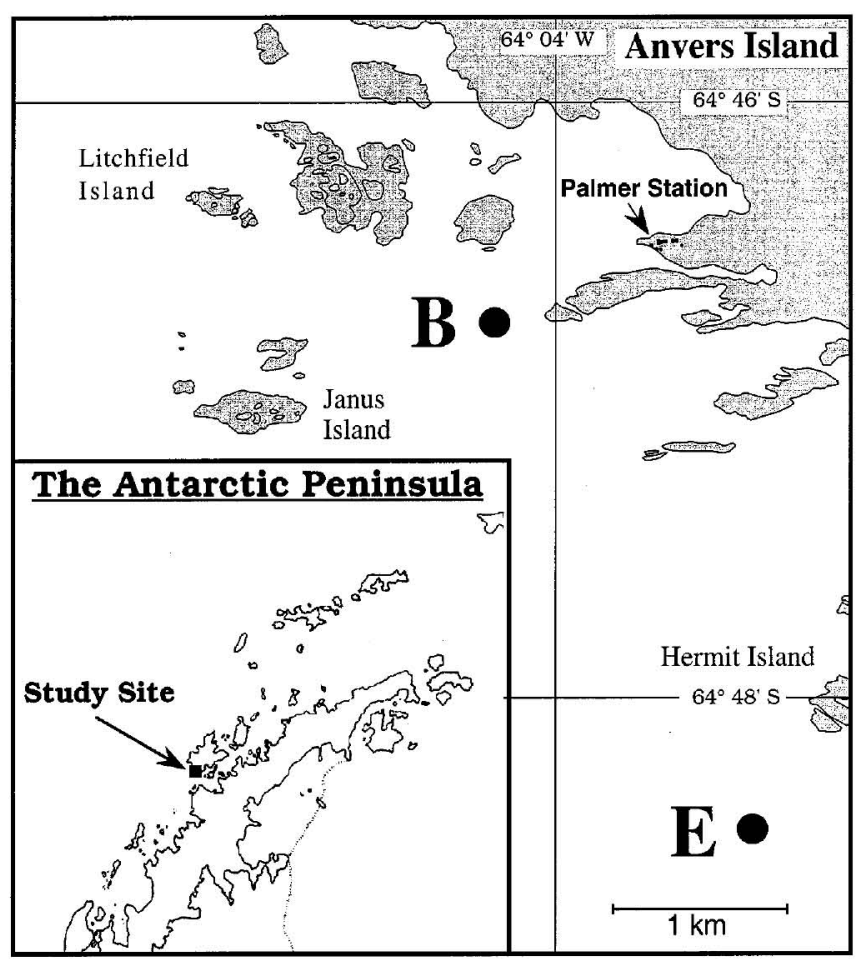

Fig. 1 Location of LTER sampling stations B $\left(64^{\circ} 46.45^{\prime} \mathrm{S}\right.$, $\left.64^{\circ} 03.27^{\prime} \mathrm{W}\right)$ and E $\left(64^{\circ} 48.90^{\prime} \mathrm{S}, 64^{\circ} 02.43^{\prime} \mathrm{W}\right)$ with respect to Palmer Station and the Antarctic Peninsula (inset) 
Table 1 Symbols and abbreviations

\begin{tabular}{|c|c|}
\hline Abbreviation & Meaning \\
\hline Chl $a$ & Chlorophyll $a$ \\
\hline$K_{\mathrm{par}}^{-1}$ & First optical depth (m) \\
\hline$C_{\mathrm{K}}$ & $\begin{array}{l}\text { Chlorophyll } a \text { concentration integrated } \\
\text { to } K_{\text {par }}^{-1}\left(\mathrm{mg} \mathrm{m}^{-2}\right)\end{array}$ \\
\hline$P_{\mathrm{K}}$ & $\begin{array}{l}\text { Primary production integrated } \\
\text { to } K_{\text {par }}^{-1}\left(\mathrm{~g} \mathrm{C} \mathrm{m}^{-2} \mathrm{day}^{-1}\right)\end{array}$ \\
\hline$C_{\mathrm{SAT}}$ & $\begin{array}{l}\text { Satellite-weighted chlorophyll } a \text { concentration } \\
\left(\mathrm{mg} \mathrm{m}^{-2}\right)\end{array}$ \\
\hline$P_{\mathrm{SAT}}$ & $\begin{array}{l}\text { Satellite-weighted primary production } \\
\left(\mathrm{g} \mathrm{C} \mathrm{m}^{-2} \text { day }^{-1}\right)\end{array}$ \\
\hline$C_{\mathrm{T}}$ & $\begin{array}{l}\text { Total integrated chlorophyll } a \text { concentration } \\
\left(\mathrm{mg} \mathrm{m}^{-2}\right)\end{array}$ \\
\hline$P_{\mathrm{T}}$ & $\begin{array}{l}\text { Total integrated primary production } \\
\left(\mathrm{g} \mathrm{C} \mathrm{m}^{-2} \mathrm{day}^{-1}\right)\end{array}$ \\
\hline$f(z)$ & Satellite weighting factor (dimensionless) \\
\hline PAR & $\begin{array}{l}\text { Photosynthetically available radiation } \\
(400-700 \mathrm{~nm})\left(\mu \mathrm{mol} \text { quanta } \mathrm{m}^{-2} \mathrm{~s}^{-1}\right)\end{array}$ \\
\hline$K$ & Attenuation length $\left(\mathrm{m}^{-1}\right)$ \\
\hline$z$ & Sample depth (m) \\
\hline
\end{tabular}

accessory pigments and the total $\mathrm{Chl} a$, the percent contribution of each taxonomic group to the overall biomass was calculated (Everitt et al. 1990; Claustré et al. 1997).

Surface and in-water photosynthetically available radiation (PAR) measurements

Methods for surface and in-water PAR (400-700 nm) measurements made during the three seasons are detailed in Moline and Prézelin (1997). PAR measurements were performed using an inwater Li-Cor LI-190SA quantum scalar irradiance sensor and an identical reference sensor. Intercalibration of the sensors between years showed a difference of $<1 \%$. In-water and reference light data were used to calculate the attenuation coefficient for downwelling $\operatorname{PAR}\left[K_{\mathrm{d}}(\mathrm{PAR}, z)\right]$ and the percent PAR at each sampling depth, which was assumed not to change over the course of a day. For all 3 years, sampling was conducted within $2 \mathrm{~h}$ of local solar noon.

Primary production calculations

Estimates of in situ primary production rates were derived from photosynthesis-irradiance $(P-E)$ relationships measured for 756 discrete water samples. The $P-E$ procedures are further detailed in Moline and Prézelin (1997). Non-linear curve fits for $P-E$ data were calculated using the Simplex method of Caceci and Cacheris (1984). Curve-fitting analyses allowed for derivation of photosynthetic parameters, including $P_{\max }\left(\mathrm{mg} \mathrm{C} \mathrm{mg} \mathrm{Chl} l^{-1} \mathrm{~h}^{-1}\right)$, the lightsaturated photosynthetic potential, $E_{\mathrm{k}}\left(\mu \mathrm{mol}\right.$ quanta $\left.\mathrm{m}^{-2} \mathrm{~s}^{-1}\right)$, an estimate of the minimum irradiance required to saturate photosynthesis, $\alpha\left[\mathrm{mg} \mathrm{C} \mathrm{mg} \mathrm{Chl} l^{-1} \mathrm{~h}^{-1}\left(\mu \mathrm{mol} \text { quanta } \mathrm{m}^{-2} \mathrm{~s}^{-1}\right)^{-1}\right]$, the lightlimited photosynthetic efficiency, $\beta$ [mg C mg Chl ${ }^{-1} \mathrm{~h}^{-1}$ ( $\mu \mathrm{mol}$ quanta $\left.\left.\mathrm{m}^{-2} \mathrm{~s}^{-1}\right)^{-1}\right]$, the efficiency of photoinhibition, and $E_{\mathrm{t}}$ ( $\mu$ mol quanta $\mathrm{m}^{-2} \mathrm{~s}^{-1}$ ), the irradiance threshold for the onset of photoinhibition.

In addition to measuring the "instantaneous" $P-E$ parameters, weekly determinations were made of the diel periodicity (3-h resolution) for each $P-E$ parameter for samples collected from both the surface and Chl $a$ maximum. These diel studies were used to correct the instantaneous measurements for time of day and increase the accuracy of estimates of in situ daily primary production (Moline and Prézelin 1997). The resulting $P$-E parameters determined for every 2 -h interval over the day were combined with modeled clear-sky PAR (z) (D. Antoine, according to Morel 1991) for calculating primary production.
Primary production was calculated at each depth at 2-h intervals over the day $[P(z, t)]$ using the hyperbolic tangent model of Platt and Gallegos (1980), such that:

$P(z, t)=P_{\max }(z, t) \cdot \tanh \left(\frac{\operatorname{PAR}(z, t)}{E_{\mathrm{k}}(z, t)}\right)$

when $\operatorname{PAR}(z, t)$, the measured integrated in situ irradiance for each 2-h interval, was less than $E_{\mathrm{t}}(z, t)$ and

$$
\begin{aligned}
P(z, t)= & P_{\max }(z, t) \cdot \tanh \left(\frac{\operatorname{PAR}(z, t)}{E_{\mathrm{k}}(z, t)}\right) \\
& \cdot \exp \left[-\beta\left(\operatorname{PAR}(z, t)-E_{\mathrm{t}}(z, t)\right)\right]
\end{aligned}
$$

when PAR $(z, t)$ was greater than $E_{\mathrm{t}}(z, t)$ (Neale and Richerson 1987). Daily rates of in situ production were computed as the sum of the 12 daily 2 -h intervals.

Estimates of satellite-derived biomass and primary productivity

Satellite-derived biomass $(C)$ was estimated in two ways: (1) by integration to the depth of the first attenuation length $\left(K_{\mathrm{par}}^{-1} ; C_{\mathrm{K}}\right)$, and (2) by depth-weighting Chl $a$ in the upper water column according to Gordon and Clark (1980), where

$C_{\mathrm{SAT}}=\frac{\int_{0}^{z} C(z) f(z) \mathrm{dz}}{\int_{0}^{z} f(z) \mathrm{dz}}$

and

$f(z)=\exp \left[-\int_{0}^{z} 2 K_{\mathrm{d}}(\mathrm{PAR}, z) \mathrm{dz}\right]$

where $f(z)$ is the exponential weighting function that accounts for arriving irradiance having been attenuated differentially with each depth to the first optical depth $(z)$ and returned to the surface by the same factor (Bukata et al. 1995). Primary production was similarly integrated to the $K_{\mathrm{par}}^{-1}\left(P_{\mathrm{K}}\right)$ with estimates of the satellite-derived primary production $\left(P_{\mathrm{SAT}}\right)$ calculated in the same manner as $C_{\mathrm{SAT}}$ by combining Eqs. 1 and 2 in Eq. 3 and replacing $C(z)$ with $P(z, t)$.

\section{Results and discussion}

During the springs and summers of 1991-1994, Case 1 waters dominated the shallow $(70 \mathrm{~m})$ nearshore coastal waters located in Palmer Basin (Sta B) and the deeper $(>200 \mathrm{~m})$ waters located in the Gerlache Strait (Sta E) (Fig. 1). From 223 profiles collected during this study, we determined that $84 \%$ of the profiles qualified as Case 1 waters, by comparing the integrated water column Chl $a$ $\left(\mathrm{mg} \mathrm{m}^{-2}\right)$ with respect to the $1 \%$ light (Fig. 2). The lack of river input in this area is a likely reason why Case 1 waters were prevalent. Case 2 waters were evident in $16 \%$ of the profiles. The designation of Case 2 waters was highly correlated with the presence of a lens of low-salinity surface waters arising from melting glacial ice. The extent of glacial ice melt in the region varied from year to year but its influence on near-surface salinity has been detected locally as far as $60-80 \mathrm{~km}$ offshore (Moline et al., in press; Prézelin et al., in press). The cloudiness of the surface waters due to glacial flour significantly increased the attenuation of light in the water column. However, as glacial flour sedimented out of the surface waters, Case I conditions quickly returned. 


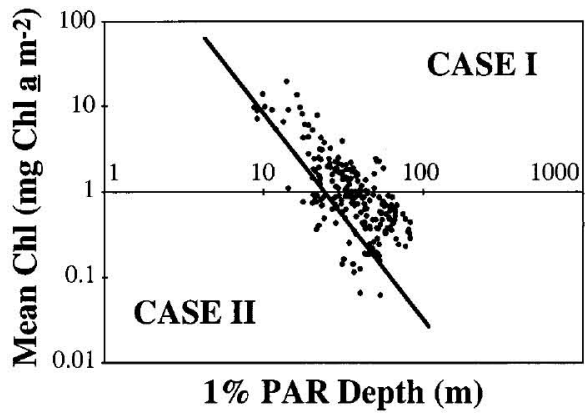

Fig. 2 Optical water types at stations B and E from Claustré et al. (1997). Plot of mean Chl $a$ within the euphotic zone (Ze) versus Ze depth. The line $[\log 10(\mathrm{Chl} a)=-2.40(\log 10(\mathrm{Ze}))+3.40]$ is given by Morel (1988) as a criterion to differentiate Case 1 waters (right side of line) from Case 2 waters (left side of line)

Chl $a$ distribution and optical depths

The temporal variability in the vertical distribution of $\mathrm{Chl} a$ and its influence on optical depths are illustrated in Fig. 3. The depth-dependent variations in biomass and optical depths for Sta B and Sta E are given in the first and third row of panels of Fig. 3. For comparison, the optical depth-dependent distributions of $\mathrm{Chl} a$ are shown in the second and fourth row of panels. On time scales as short as a few days, there are several-fold changes in $C_{\mathrm{T}}$, with corresponding impacts on the water column optical depths. Water column Chl $a\left(C_{\mathrm{T}}\right)$ varied by more than 3 orders of magnitude, with values ranging from 0.3 to more than $450 \mathrm{mg} \mathrm{Chl} a \mathrm{~m}^{-2}$. The depth of the euphotic zone varied by 1 order of magnitude, with the $0.1 \%$ PAR depth ranging from 10 to $\sim 100 \mathrm{~m}$ (Fig. 3). Generally, the variability was as great or greater within a year as between years (Moline and Prézelin 1996).

Large changes in Chl $a$ vertical distribution occurred on short time scales. One example was at Sta E in December 1991 when there were three distinct episodes of elevated Chl $a$ within a single month. In the first event, high biomass concentrations were observed throughout the photic zone. In the second event, Chl $a$

Fig. $3 \mathrm{Chl} a$ as a function of depth (m) and as a function of optical depth $\left[K_{\mathrm{d}}(\mathrm{PAR}, \bullet \mathrm{z}) z\right]$ for stations B and E from December 1991 to February 1994. Chl $a$ scale for the $1992-1994$ seasons is $0-3 \mathrm{mg}$ Chl $a \mathrm{~m}^{-3}$, with the scale for the 1991-1992 season ranging from 0 to $5 \mathrm{mg} \mathrm{Chl} a \mathrm{~m}^{-3}$. Included in the upper panels for each station are the depths of the upper attenuation length (bold white lines) and $0.1 \%$ PAR light level (thin white lines). The presence of ice is indicated by hatched bars (1993-1994)

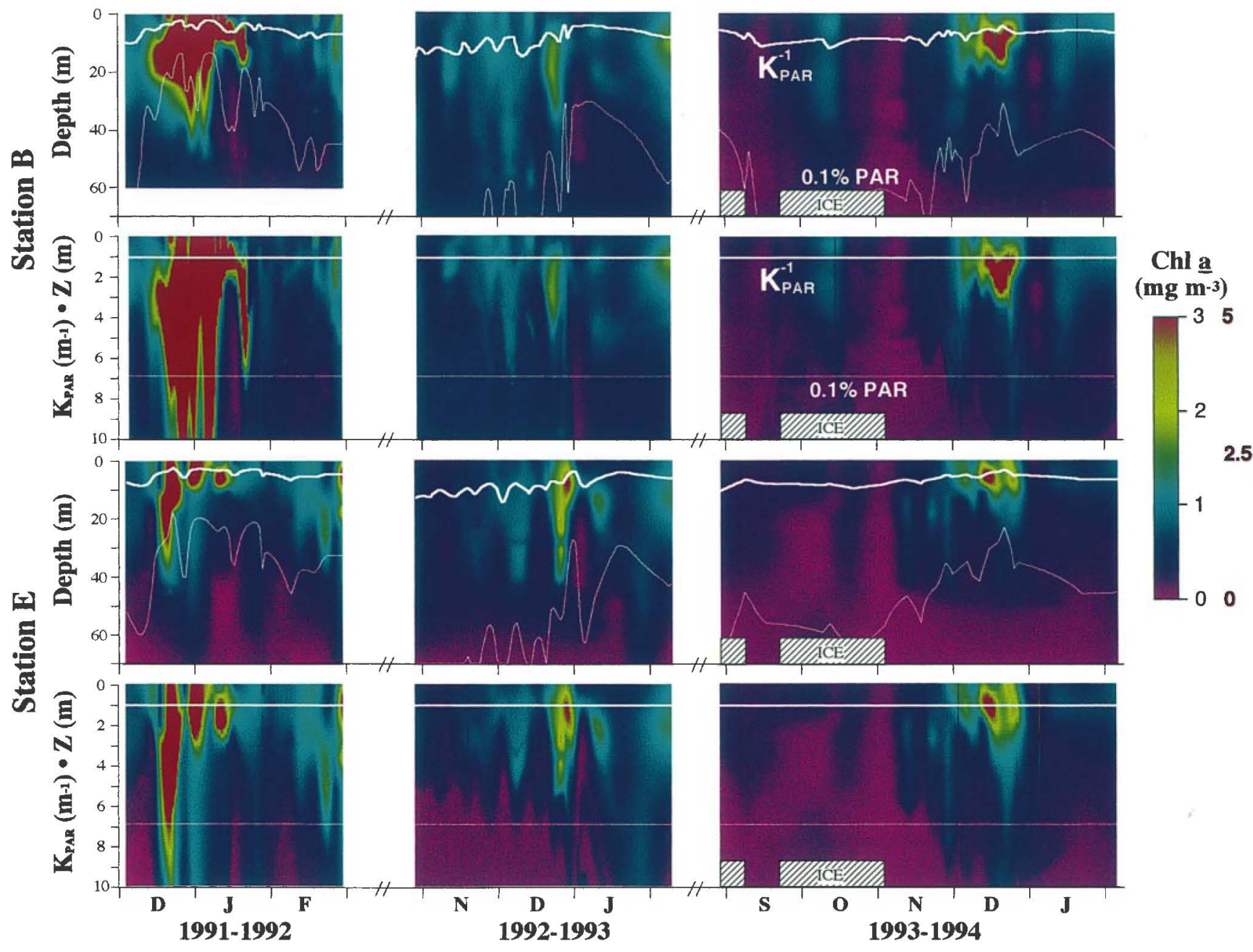


was elevated within the upper $10 \mathrm{~m}$ and, of this, about half was below $K_{\mathrm{par}}^{-1}$. In the third event, the majority of Chl $a$ was below $K_{\text {par }}^{-1}$. From a satellite perspective, the first two events would appear with similar intensity in remotely sensed images, while the significance of the third event may be underestimated. Similar changes occurred at Sta B during the initiation of the large bloom (1991-1992) and during the increased biomass signals in 1992-1993 and 1993-1994 (Fig. 3). With all of these events, the majority of the Chl $a$ was sub-surface and below the first optical depth.

One assumption commonly made in satellite oceanography is that the amount of Chl within the first attenuation length $\left(C_{\mathrm{K}}\right)$ approximates to satellite-weighted estimates of Chl $a$ in the upper water column (cf. Kirk 1994; Mobley 1994). The satellite-based estimate of Chl $a$ $\left(C_{\mathrm{SAT}}\right.$, Eq. 3$)$ is exponentially weighted to account for arriving irradiance having been attenuated differently with each depth to the first optical depth $(z)$ and returned to the surface by the same factor (Bukata et al. 1995). The results of a test of this assumption are presented in Fig. 4A. In spite of an excellent correlation between $C_{\mathrm{K}}$ and $C_{\mathrm{SAT}}\left(r^{2}=0.95\right)$, we determined that less than half of the Chl $a$ within the first optical depth would be predicted by satellite-weighted estimates. On average, $57 \%$ of the integrated $\mathrm{Chl} a$ measured within the first optical depth was unaccounted for in the satellite-weighted Chl $a$ estimates. Next, we tested the common assumptions that a fixed relationship exists between total water column $\mathrm{Chl}$ $a\left(C_{\mathrm{T}}\right)$ and $C_{\mathrm{K}}$ (Fig. 4B) and between $C_{\mathrm{T}}$ and $C_{\mathrm{SAT}}$ (Fig. 4C). In approximately two-thirds of the measurements, $C_{\mathrm{T}}$ could be predicted from both $C_{\mathrm{SAT}}$ and $C_{\mathrm{K}}$. On average, $C_{\mathrm{K}}$ was $20 \%$ of the total integrated $\mathrm{Chl} a$ while $C_{\mathrm{SAT}}$ was $8.5 \%$. The best agreement for both relationships occurred at lower $\mathrm{Chl} a$ concentrations.

A major objective of satellite observations is to predict primary production from knowledge of surface radiation and the distribution of Chl $a$ in the water column. These relationships for the present data set are given in Fig. 5. A fairly strong correlation $\left(r^{2}=0.80\right)$ existed between the measured total integrated biomass $\left(C_{\mathrm{T}}\right)$ and measured primary productivity $\left(P_{\mathrm{T}}\right)$ for all years/stations (Fig. 5A; Moline and Prézelin 1996). The high range in the data is a reflection of the diversity of water types observable in coastal waters of the Southern Ocean. The mean ratio of $P_{\mathrm{T}}: C_{\mathrm{T}}$ for the water column $\left(25 \mathrm{mgC}\right.$ day $^{-1}$ $\mathrm{mgChl} a^{-1}$ ) was generally exceeded during periods of low light attenuation, with lower values attributable to bloom periods and higher attenuation.

The relationship between $P_{\mathrm{K}}$ and $C_{\mathrm{K}}$ (Fig. 5B) was much weaker than that for $P_{\mathrm{T}}$ and $C_{\mathrm{T}}$, with $C_{\mathrm{K}}$ predicting only $57 \%$ of the variance in $P_{\mathrm{K}}$. Satelliteweighted Chl $a$ similarly predicted the measured in situ primary production in only half of the data, with an average ratio of $P_{\mathrm{SAT}}: C_{\mathrm{SAT}}$ of $210 \mathrm{mgC} \mathrm{day}^{-1} \mathrm{mgChl} a^{-1}$ (Fig. 5C). These results suggest Chl-specific production values have a higher variance in the surface waters viewed by ocean color satellites than throughout the water column.
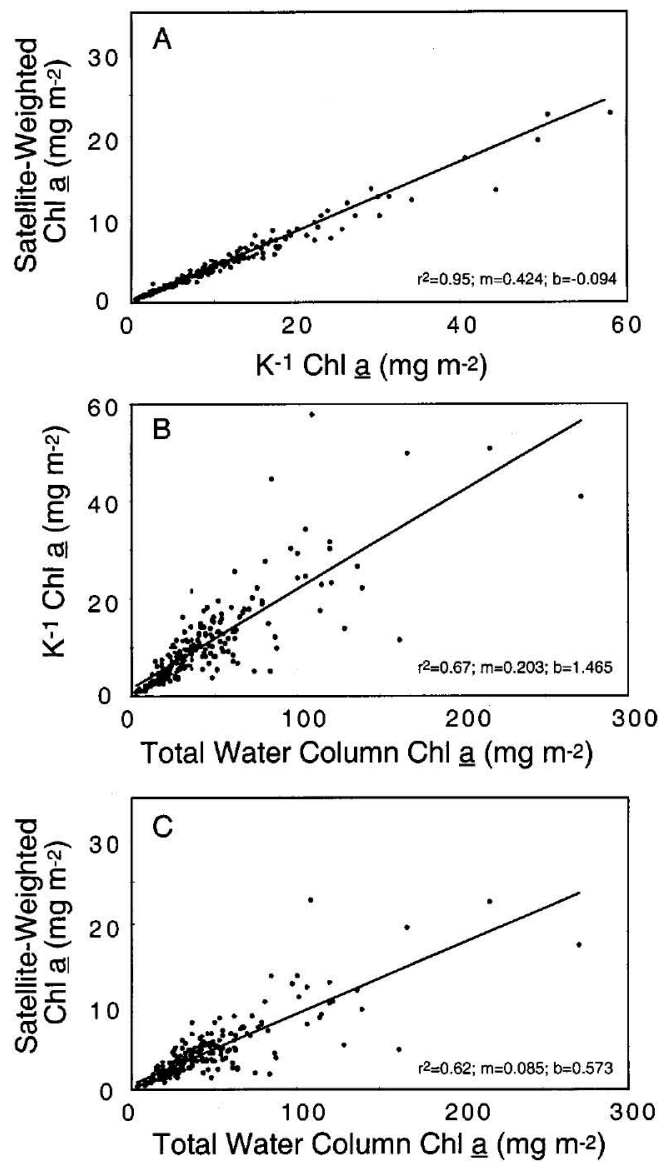

Fig. 4 Comparison of $\mathrm{Chl} a$ biomass within $\mathbf{A}$ the first attenuation length $\left(C_{\mathrm{K}}\right)$ versus the satellite-weighted depth $\left(C_{\mathrm{SAT}}\right)$, B the total water column $\left(C_{\mathrm{T}}\right)$ versus $C_{\mathrm{K}}$, and $\mathbf{C} C_{\mathrm{T}}$ versus $C_{\mathrm{SAT}}$. Slope $(m)$ and intercept $(b)$ parameters from the best-fit line are included. Data are from stations $\mathrm{B}$ and $\mathrm{E}$ for all three seasons $(n=223)$

The low overall predictability of primary production from Chl $a$ estimates (Fig. 5C) was largely attributed to the underlying variance associated with the $\mathrm{Chl} a$ depth distribution (Fig. 4). While the fractions $C_{\mathrm{K}}: C_{\mathrm{T}}$ and $C_{\mathrm{SAT}}: C_{\mathrm{T}}$ were relatively consistent between years/ stations $\left(\right.$ Fig. $5 ; C_{\mathrm{SAT}}: C_{\mathrm{T}}=0.102 \pm 0.036 ; C_{\mathrm{K}}: C_{\mathrm{T}}=$ $0.242 \pm 0.083)$, there were periods when they significantly increased or decreased more than ninefold over the course of only a few days (Fig. 6). This variance was higher for our Southern Ocean data set than those reported in past studies conducted at other latitudes (Smith and Baker 1978). The range of $C_{\mathrm{SAT}}: C_{\mathrm{T}}$ in this study encompasses the range generally found as one moves from eutrophic coastal conditions $\left(C_{\mathrm{SAT}}: C_{\mathrm{T}}=\right.$ $0.13)$ to near-coastal waters $\left(C_{\mathrm{SAT}}: C_{\mathrm{T}}=0.10\right)$ and offshore to oligotrophic seas $\left(C_{\mathrm{SAT}}: C_{\mathrm{T}}=0.05\right.$; derived from Smith 1981).

At the onset of the bloom in 1991, sub-surface Chl $a$ maxima were measured, causing $C_{\mathrm{K}}$ and $C_{\mathrm{SAT}}$ fractions to drop fourfold from pre-bloom conditions (Fig. 6). From this initial condition, there were two competing processes during the bloom that caused $C_{\mathrm{K}}$ and $C_{\mathrm{SAT}}$ fractions to fluctuate. As water column $\mathrm{Chl} a$ concentrated 

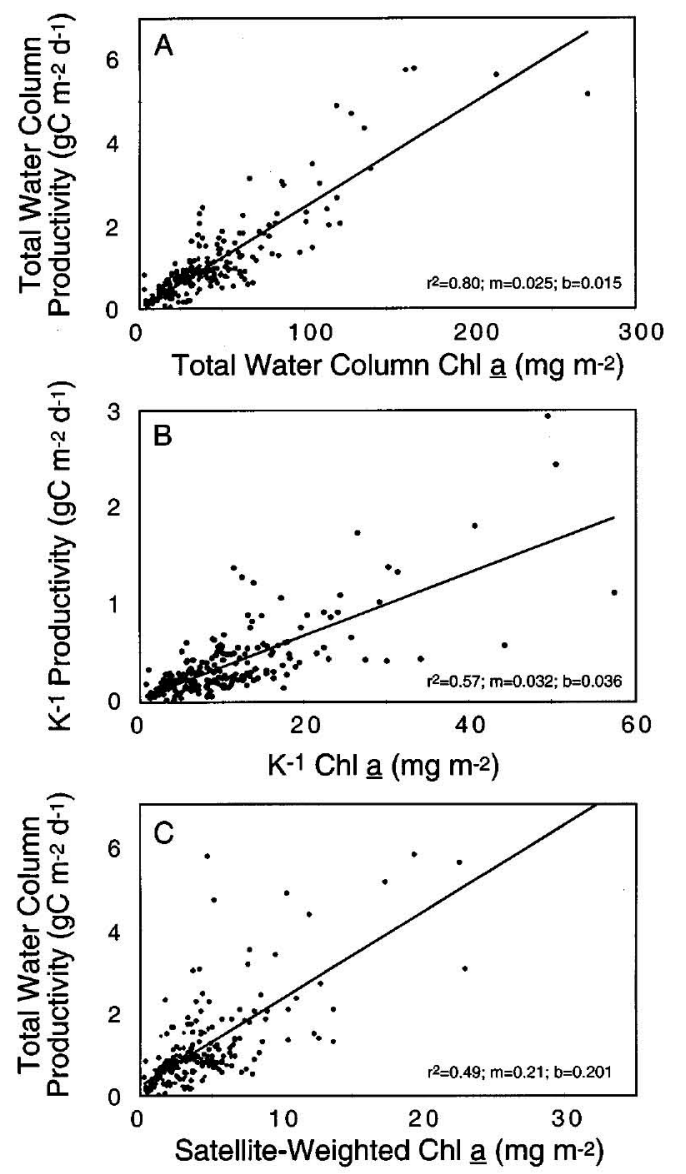

Fig. 5 Comparison between chlorophyll biomass and productivity for the A total water column $\left(C_{\mathrm{T}}\right.$ vs $\left.P_{\mathrm{T}}\right)$, $\mathbf{B}$ for the first attenuation length $\left(C_{\mathrm{K}}\right.$ vs $\left.P_{\mathrm{K}}\right)$, and $\mathbf{C}$ the relationship between $C_{\mathrm{SAT}}$ and total water column productivity. Slope $(m)$ and intercept $(b)$ parameters from the best-fit line are included. Data are from stations B and E from 1991$1994(n=223)$

above the rapidly shallowing pycnocline (Moline and Prézelin 1996) and photoadaptive increases in cellular pigmentation occurred due to low-light conditions within the bloom (Moline 1998), both $C_{\mathrm{K}}$ and $C_{\mathrm{SAT}}$ fractions steadily increased. High turnover rates (Moline and Prézelin 1996) and decreased turbulence (Moline 1998) also increased the downward flux of cells, distributing a larger fraction of cells below the first optical depth. Although the depth of the euphotic zone decreased during the blooms, the number of viable cells at lower light levels increased, and therefore also increased the proportion of productivity below the first optical depth. These results have implications for remote sensing of other highly productive areas in the Southern Ocean (i.e. Marginal Ice-Edge Zones), with increased attenuation as well as increasing sinking rates leading to significant underestimates of both phytoplankton standing stock and productivity in these regions. Dynamics during this event illustrate that even within bloom conditions, the $C_{\mathrm{SAT}}$ fraction is subject to dynamic changes that are not necessarily predictable.

The fractions of $C_{\mathrm{K}}$ and $C_{\mathrm{SAT}}$ to $C_{\mathrm{T}}$ generally decreased when phytoplankton blooms occurred at the study site. When total integrated Chl $a$ was less than $100 \mathrm{mg} \mathrm{m}^{-2}$, the satellite-weighted depth consistently represented $10 \%$ of this total. The fraction of $C_{\mathrm{SAT}}: C_{\mathrm{T}}$ declined significantly (ANOVA, $P<0.02$ ) to approximately $6 \%$ when integrated $\mathrm{Chl} a$ exceeded $100 \mathrm{mg} \mathrm{m}^{-2}$ (Fig. 7A). Similar findings were reported by Morel (1991) for temperate coastal environments. Such events in this study were episodic and evident to varying degrees for both stations over all 3 years (Fig. 6).

Taxonomic influence on Chl $a$ distribution and optical depths

Increases in the $C_{\mathrm{K}}$ and $C_{\mathrm{SAT}}$ fractions were measured every summer when diatom-dominated communities were replaced by cryptophytes (Fig. 6; Moline and Prézelin 1996; Claustré et al. 1997). Cryptophyte populations were always found restricted to the near-surface waters and initially increased the proportion of the total water column biomass in $C_{\mathrm{K}}$ and $C_{\mathrm{SAT}}$. As the percentage of cryptophytes increased, the average $C_{\mathrm{SAT}}: C_{\mathrm{T}}$ ratios rose significantly about $40 \%$ from 0.09 to 0.14 (ANOVA, $P<0.05$; Fig. 7B). When cryptophytes were still dominant with biomass exceeding $100 \mathrm{mg} \mathrm{m}^{-2}$, Chl $a$ was no longer confined to the surface waters and the $C_{\mathrm{SAT}}: C_{\mathrm{T}}$ and $C_{\mathrm{K}}: C_{\mathrm{T}}$ declined (see station E 1992 1993 and 1993-1994; Fig. 6).

The taxonomic influence on the depth distribution of Chl $a$ is perhaps the most novel finding of this study. While the zonation of various algal groups within the water column was documented long ago (Ryther and Hulbut 1960), the influence of taxonomy on the Chl $a$ distribution has received little attention. The recurrent dominance of surface cryptophyte populations during the summer months significantly increased the proportion of Chl $a$ in the upper water column and was responsible for the highest variability within and between years. The restriction of cryptophytes to the surface waters is thought to be due to a combination of their motility, allowing them to resist vertical mixing and remain in the euphotic zone, and their apparent preference for lower salinity environments (Moline et al., in press), which explains their high concentrations during the summer months when there is significant meltwater input into the coastal regions of the Antarctic Peninsula.

The implications of taxonomy to remote sensing applications have received little attention. This is primary due to the difficulty of optically distinguishing between phytoplankton groups (Garver et al. 1994). Claustré et al. (1997), however, quantified a twofold change in $\Psi^{*}$, the photosynthetic cross section (Morel 1991), as a result of shifts in the phytoplankton community composition and stressed the importance of taxonomy when deriving productivity algorithms from biomass estimates. Cryptophytes possess phycobiliproteins (either phycocyanin or phycoerythrin; Rowan 1989), which absorb in the green-orange wavelengths. These water-soluble pigments are shared with only one other 


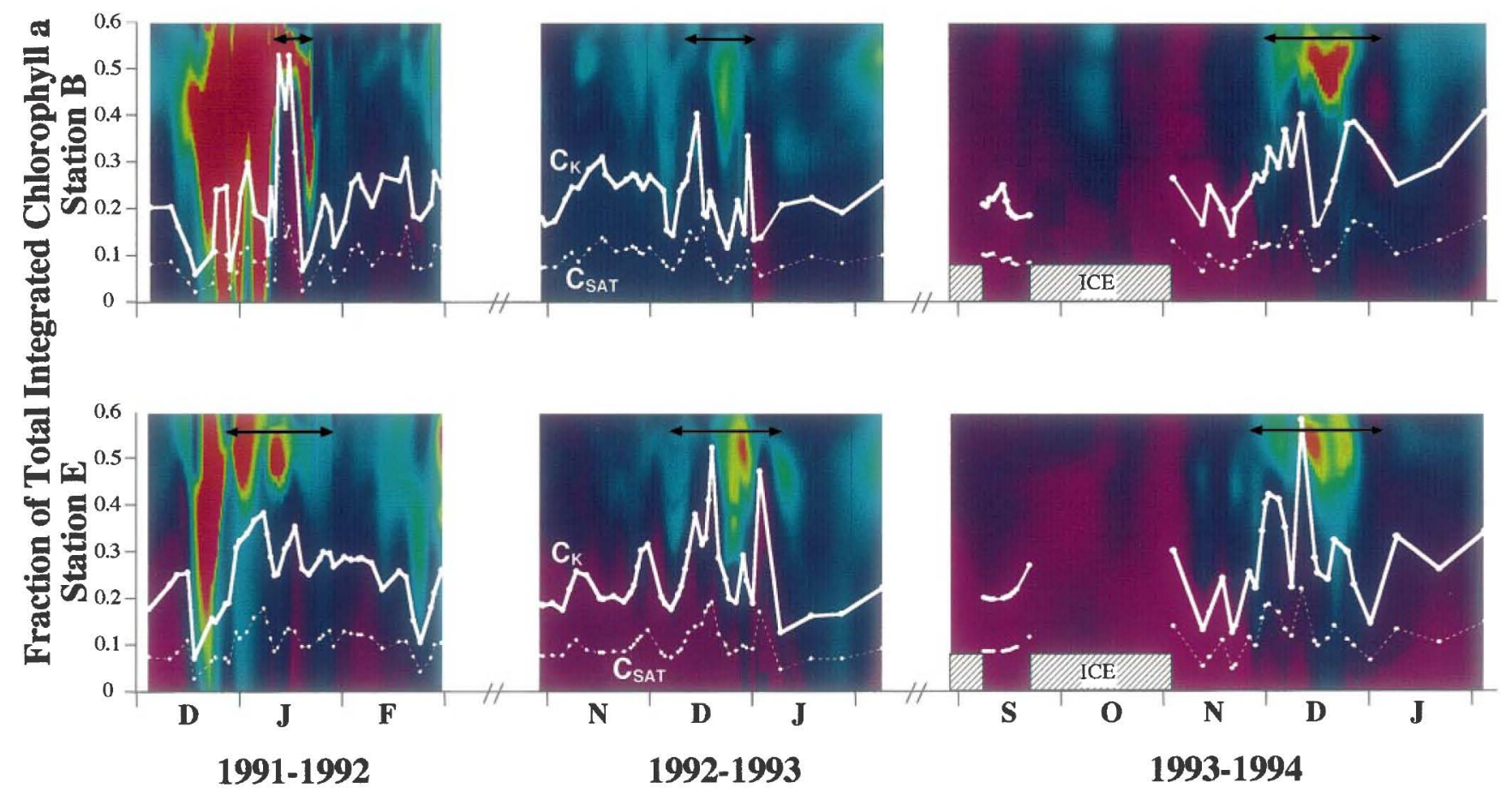

Fig. 6 Fraction of total $\mathrm{Chl} a$ within the upper attenuation length ( filled circles/bold lines) and satellite-weighted biomass ( filled circles/ dotted line) for stations B and E from 1991-1994. Fractions of the total Chl $a$ are overlaid on the contours from Fig. 3 of Chl $a$ as a function of optical depths. Black arrows represent the periods when cryptophytes accounted for more than $50 \%$ of the total Chl $a$. The presence of ice is indicated by hatched bars (1993-1994)

phytoplankon group, cyanobacteria. Since cyanobacteria are scarce in the Southern Ocean (Waterbury et al. 1987), cryptophytes may be distinguishable from other phytoplankton groups using in-water optical sensors and/or the new generation of higher spectral resolution sensors (i.e. SeaWIFS, MODIS). Given this, cryptophyte-induced changes in the depth distribution of Chl $a$ and photosynthetic capacity (Claustré et al. 1997) may be detectable and their unique effect on biomass distribution incorporated into existing algorithms to more accurately assess integrated water column biomass and productivity.

\section{Conclusions}

While there are outstanding technical issues to resolve in nearshore waters for remote sensing, such as landocean interfaces (especially in high-latitude snow- and ice-covered areas with high albedo), the Palmer Basin waters are predominantly Case I waters, making this area suitable for coastal remote sensing applications. Despite the large temporal variability in Chl $a$ during the growing season, the Chl $a$ fractions in the upper euphotic zone were relatively stable and most of the variability could be explained either by bloom periods and/ or the appearance of near-surface cryptophyte populations. This study provides quantification of these sources

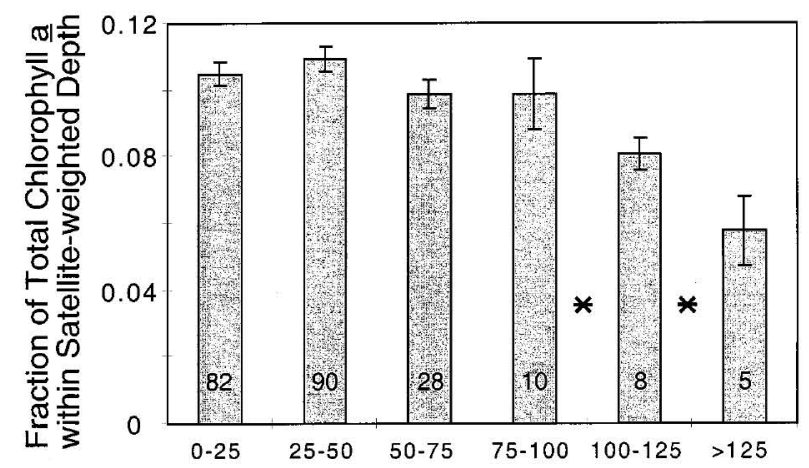

A

Chlorophyll $\underline{a}(\mathrm{mg} \mathrm{m}-2)$

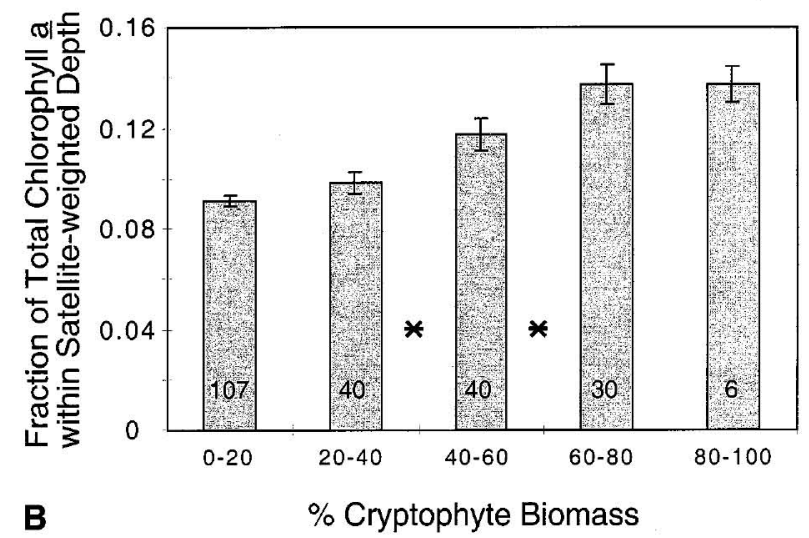

Fig. 7 A The fraction of $\mathrm{Chl} a$ within the satellite-weighted depth as a function of total integrated $\mathrm{Chl} a$. Chl $a$ profiles from all stations and years are binned in six intervals $(n=223)$. B The fraction of Chl $a$ within the satellite-weighted depth as a function of the percent contribution of cryptophytes to the total biomass. Included are the number of profiles and the standard error for each interval. Significance (ANOVA, $P<0.05$ ) between intervals in both panels is indicated by asterisks 
of variability and illustrates the need to consider phytoplankton community composition in future remote sensing efforts in the Southern Ocean.

Acknowledgements B. Boczar, N. Boucher, T. Diem, T. Evens, B. Golden, P. Handley, R. Jovine, H. Matlick, T. Newberger, S. Roll, K. Seydel, K. Scheppe, O. Schofield, J. Standish, B. Sullivan, T. Westerberry and the ASA personnel are acknowledged for their tireless assistance in collection of the field data. We also thank R. Bidigare and M. Ondrusek for providing HPLC pigment standards. H. Claustré and O. Schofield gave generously of their time to provide valuable insights, discussion, and comments. We also thank R. Vaillancourt, O. Holm-Hansen, and an anonymous reviewer for their constructive comments. This study was supported by National Science Foundation grant DPP 90-901127 to B.B. Prézelin.

\section{References}

Arrigo KR, McClain CR, Firestone JK, Sullivan CW, Comiso JC (1994) A comparison of CZCS and in situ pigment concentrations in the Southern Ocean. NASA Tech Memo 104566:30-34

Arrigo KR, Worthen D, Schnell A, Lizotte MP (1998) Primary production in Southern Ocean waters. J Geophys Res 103:15587-15600

Berhrenfeld MJ, Falkowski PG (1997) A consumer's guide to phytoplankton primary productivity models. Limnol Oceanogr 42:1479-1491

Bukata RP, Jerome JH, Kondratyev KY, Pozdnyakov DV (1995) Optical properties and remote sensing of inland and coastal waters. CRC Press, Boca Raton

Caceci MS, Cacheris WP (1984) Fitting curves to data. Byte 9:340362

Claustré H, Moline MA, Prézelin BB (1997) Sources of variability in the photosynthetic cross-section for Antarctic coastal waters. J Geophys Res 102:25047-25060

Everitt DA, Wright SW, Volkman JK, Thomas DP, Lindstrom EJ (1990) Phytoplankton community compositions in the western equatorial Pacific determined from chlorophyll and carotenoid pigment distribution. Deep Sea Res 37:975-997

Garver SA, Siegel DA, Mitchell BG (1994) Variability in nearsurface particulate absorption spectra: what can a satellite ocean color imager see? Limnol Oceanogr 39:1349-1367

Gieskes WWC, Kraay GW (1983) Dominance of Cryptophyceae during the phytoplankton spring bloom in the central North Sea detected by HPLC analysis of pigments. Mar Biol 75:179185

Gordon HR, Clark DK (1980) Remote sensing optical properties of a stratified ocean. Appl Opt 19:3428-3430

Gordon HR, Morel A (1983) Remote assessment of ocean color for interpretation of satellite visible imagery. In: Barber RT, Mooers NK, Bowman MJ, Zeitzchel (eds) Lecture notes on coastal and estuarine studies. Springer, Berlin, Heidelberg, New York

Holm-Hansen O, Mitchell BG (1991) Spatial and temporal distribution of phytoplankton and primary production in the western Bransfield Strait region. Deep Sea Res 38:961-980

Kirk JTO (1994) Light and photosynthesis in aquatic ecosystems. Cambridge University Press, Cambridge

Lewis MR (1991) Satellite ocean color observations of global biogeochemical cycles. In: Falkowski PG, Woodhead AV (eds) Primary productivity and biogeochemical cycles in the sea. Plenum Press, New York, pp 139-154

Mobley CD (1994) Light and water: radiative transfer in natural waters. Academic Press, San Diego

Moline MA (1998) Photoadaptation response during the development of a coastal Antarctic diatom bloom and relationship to water column stability. Limnol Oceanogr 43:146-153
Moline MA, Prézelin BB (1996) Palmer LTER 1991-1994: longterm monitoring and analyses of physical factors regulating variability in coastal Antarctic phytoplankton biomass, in situ productivity and taxonomic composition over subseasonal, seasonal and interannual time scales. Mar Ecol Prog Ser 145:143-160

Moline MA, Prézelin BB (1997) High-resolution time-series data for primary production and related parameters at a Palmer LTER coastal site: implications for modeling carbon fixation in the Southern Ocean. Polar Biol 17:39-53

Moline MA, Claustré H, Frazer T, Grymski J, Schofield O, Vernet $M$ (in press) Changes in phytoplankton assemblages and potential implications for the Antarctic food web. In: Davidson B (ed) Antarctic ecosystems: models for wider ecological understanding. Cambridge University Press, Cambridge

Morel A (1988) Optical modeling of the upper ocean in relation to its biogenous matter content (Case 1 Waters). J Geophys Res 93:10,749-10,768

Morel A (1991) Light and marine photosynthesis: a spectral model with geochemical and climatological implications. Prog Oceanogr 26:263-306

Morel A, Berthon J-F (1989) Surface pigments, algal biomass profiles, and potential production of euphotic layer: relationships reinvestigated in view of remote-sensing applications. Limnol Oceanogr 34:1545-1562

Neale PJ, Richerson PJ (1987) Photoinhibition and the diurnal variation of phytoplankton photosynthesis. I. Development of a photosynthesis-irradiance model from studies of in situ responses. J Plankton Res 9:167-193

Platt T, Gallegos CL (1980) Modeling primary productivity. In: Falkowski PG (ed) Primary production in the sea. Plenum Press, New York, pp 339-362

Platt T, Sathyendranath S (1988) Oceanic primary production: estimation by remote sensing and local regional scales. Science 241:1613-1620

Prézelin BB, Hofmann EE, Mengelt C, Klinck JM (in press) The linkage between upper circumpolar deep water (UCDW) and phytoplankton assemblages on the west Antarctic Peninsula continental shelf. J Mar Res

Rowan KS (1989) The biliproteins. In: Rowan KS (ed) Photosynthetic pigments of algae. Cambridge University Press, Cambridge, pp 166-211

Ryther JH, Hulbut EM (1960) On winter mixing and the vertical distribution of phytoplankton. Limnol Oceanogr 5:337-338

Sathyendranath S, Platt T (1989) Remote sensing of ocean chlorophyll: consequences of nonuniform pigment profile. Appl Opt 28:490-495

Sathyendranath S, Platt T, Horne EPW, Harrison WG, Ulloa O, Outerbridge R, Hoepffner N (1991) Estimation of new production in the ocean by compound remote sensing. Nature 353:129-133

Smith RC (1981) Remote sensing and depth distribution of ocean chlorophyll. Mar Ecol Prog Ser 5:359-361

Smith RC, Baker KS (1978) The bio-optical state of ocean waters and remote sensing. Limnol Oceanogr 23:247-259

Smith RC, Dierssen H, Vernet V (1996) Phytoplankton biomass and productivity to the west of the Antarctic Peninsula. In: Ross RM, Hofmann EE, Quetin LB (eds) Foundations for ecological research west of the Antarctic Peninsula. AGU Antarctic Research Series, vol 70, pp 333-356

Smith RC, Baker KS, Vernet M (1998) Seasonal and interannual variability of phytoplankton biomass west of the Antarctic Peninsula. J Mar Systems 17:229-243

Waterbury JB, Stanley WW, Valois FW, Franks DG (1987) Biological and ecological characterization of the marine unicellular cyanobacterium Synechococcus. In: Platt T, Li WK (eds) Photosynthetic picoplankton. Can Bull Fish Aquat Sci 214:71-120

Wright SW, Jeffery SW, Mantoura RFC, Llewellyn CA, Bjørnland T, Repeta D, Welschmeyer N (1991) Improved HPLC method for analysis of chlorophylls and carotenoids from marine phytoplankton. Mar Ecol Prog Ser 77:183-196 